\title{
Evaluation of the surface water quality in the Itapicuru river basin - State of Bahia, Brazil
}

\author{
S. S. P. Mestrinho ${ }^{1}$, D. Reitemajer ${ }^{2}$, D. C. Porciúncula $^{2}$ \& R. Lyrio ${ }^{2}$ \\ ${ }^{1}$ Superintendence of Researches and Graduate Studies, UCSAL, Brazil \\ ${ }^{2}$ Associated Consultants, Brazil
}

\begin{abstract}
The Itapicuru River basin is located in the northeast of the State of Bahia, Brazil. It is a large basin with variable conditions in terms of soil, climate, topography, natural vegetation, and economy. About $80 \%$ of the total area is subjected to severe drought periods. Poor cropping systems and lack of adequate systems for disposing wastewater from the urban areas determine the water quality along the basin. This proposal aims to carry out a study on the actual situation of the surface water resources, including diagnostic and prognostic actions. The study presents a spatial analysis of the surface water quality using hydro chemical data of the water and sediments from 30 stations along the river and the tributaries, including points in the reservoirs of the dam and estuary region. The main processes related with the water quality are: erosion, concentrations of salt and nutrients, punctual contamination of metals and bacteria. The spatial distribution of the parameters in the different points is illustrated in maps. Zones showing higher values of coliforms, nitrogen, phosphor, chloride, conductivity and nitrates are in the high and medium part of the river, where there is low rainfall, higher demographic density and expressive social-economic dynamics. Closer to the chromium mines the concentration of iron and chromium in the sediments is above the limits. The results are associated with the environmental quality in order to have a characterization of the hydro chemical and social-economic elements, in different scales. Also critical areas are defined in detailed studies to help implement corrective actions to minimize or eliminate the contamination problems. It is expected that the results and achievements of this project will be useful in order to support the development of state and federal programs on the sustainability of water resources in the region.
\end{abstract}

Keywords: water quality, environmental quality, Itapicuru river basin. 


\section{Introduction}

The Itapicuru river basin occupies a total area of $36,440 \mathrm{~km}^{2}$, with an estimated population of 1,300,000 inhabitants. The environmental impact associated to the farming, mining, industrial, tourist activities and the disordered growth of the cities with inadequate infrastructure of sewers threaten the water quality. The basin is subdivided into four sectors with differentiated characteristics, as shown in table 1 .

Table 1: Characteristics of the main sectors of the Itapicuru River Basin (SRH [1], PRODETAB [2]).

\begin{tabular}{|c|c|c|c|c|}
\hline & $\begin{array}{c}\text { Upper } \\
\text { Sector (I) }\end{array}$ & $\begin{array}{c}\text { Middle Upper } \\
\text { Sector (II) }\end{array}$ & $\begin{array}{c}\text { Middle Lower } \\
\text { Sector (III) }\end{array}$ & $\begin{array}{c}\text { Lower } \\
\text { Sector (IV) }\end{array}$ \\
\hline 焉焉离 & $727.61 \mathrm{~mm}$ & $500.29 \mathrm{~mm}$ & $682.27 \mathrm{~mm}$ & $1,182.71 \mathrm{~mm}$ \\
\hline$\stackrel{\mathbb{E}}{\gtrless}$ & $11,968.97 \mathrm{~km}^{2}$ & $10,106.57 \mathrm{~km}^{2}$ & $12,232.01 \mathrm{~km}^{2}$ & $2,131.45 \mathrm{~km}^{2}$ \\
\hline 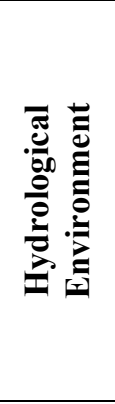 & $\begin{array}{l}\text { High declivity } \\
\text { terrain. } \\
\text { The water from } \\
\text { the rock } \\
\text { fractures } \\
\text { influences the } \\
\text { permanent flow } \\
\text { of the river. } \\
\text { Many dams. }\end{array}$ & $\begin{array}{c}\text { Crystalline } \\
\text { rocks with } \\
\text { discrete hydro } \\
\text { potentiality. } \\
\text { More saline } \\
\text { waters. Rivers } \\
\text { flow in the rainy } \\
\text { period. }\end{array}$ & $\begin{array}{l}\text { Ground that } \\
\text { favors } \\
\text { infiltration. } \\
\text { Rivers are } \\
\text { intermittent. The } \\
\text { underground } \\
\text { hydro potential } \\
\text { is high. }\end{array}$ & $\begin{array}{l}\text { Deeper } \\
\text { ground. The } \\
\text { greatest } \\
\text { rainfall rates } \\
\text { assures the } \\
\text { permanent } \\
\text { flow of the } \\
\text { small and } \\
\text { medium sized } \\
\text { rivers }\end{array}$ \\
\hline 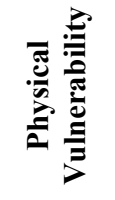 & $\begin{array}{l}\text { High and } \\
\text { medium. } \\
\text { Risk of erosion }\end{array}$ & $\begin{array}{l}\text { Medium. } \\
\text { High on some } \\
\text { points. }\end{array}$ & $\begin{array}{l}\text { Low. } \\
\text { Medium and } \\
\text { high on some } \\
\text { points. }\end{array}$ & $\begin{array}{l}\text { High. } \\
\text { Risk of } \\
\text { flooding. }\end{array}$ \\
\hline
\end{tabular}

The basin's volume of average annual precipitation is estimated to be $24,631.38 \times 10^{6} \mathrm{~m}^{3}$ and the total flow $1,269.96 \times 10^{6} \mathrm{~m}^{3}$. The superficial hydro potentiality is considered low $\left(0.76 \mathrm{1} / \mathrm{s} / \mathrm{km}^{2}\right)$. Around $80 \%$ of the area is in the conditions of semi-arid climate. The fluvial regimen in the sectors is a reflex of the regional variation of rainfall: from the middle lower sector of the river to the 
lower the flow is permanent; otherwise, at the upper and the middle upper sectors the river and its tributaries are intermittent. The state of hydro deficit has stimulated the construction of dams and the perforation of wells, to increase the availability of water in the period of greater demand.

Regionally, we don't see a control in the use of the ground and of the water and situations of aggression to the environment can be noticed, like: indiscriminant removal of the vegetation coverage; the absence of or deficient control of the activities of mining and of the launching of solid and liquid residues in the water courses; and the construction of dams without the correct management or prior study.

This work discusses the results of studies for the environmental diagnosis associated to the quality of the basin's superficial water, with the objective of guiding planning programs of its water resources and sustainable development. The research integrates the Investigation Project PRODETAB/EMBRAPA 05501/01, under the auspices of the World Bank.

\section{Methodological aspects}

The Itapicuru River is formed mainly by the confluence of the Itapicuru, Itapicuru Açu and Itapicuru Mirim rivers, and the contribution of several tributaries. To characterize the quality of the water, was established a sample grid of 30 points for water collection and 20 points for sediments. The territorial extent of the basin is large, and although the number of points is limited, the sample contemplates the sections of the main course of the river and its tributaries (R1, R2,..., R23), including the reservoirs (B1, B2,..., B7). Two stages of fieldwork were carried out in distinct seasons: August 2005 (greater indices of rainfall) and January of 2006 (less rainfall). The standards recommended by APHA [3] were used as techniques for the samples collection and analyses. For each point the following variables were investigated: conductivity, chlorides, total nitrogen and phosphor, nitrates, thermo-tolerant coliforms, Trophic State Index - TSI introduced by Carlson [4], Water Quality Index - WQI National Sanitation Foundation - U.S.A., and the level of metal in the sediments.

In order to illustrate the information obtained, geoprocessing techniques were used to permit a spatial reading of the territory using maps in the regional scale $(1: 1,000,000)$. The final approach includes an analysis of the environmental quality of the basin, integrating other specifics information available in the scope of the Project PRODETAB/EMPRAPA.

\section{Results and discussion}

The basin of the river Itapicuru covers diverse climatic, geologic, geomorphologic environments and distinct ecosystems. The comprehension of the social-environmental dynamics, which influences the quality of the water resources, demands the integration of the variable information. As a methodological basis for the construction of the basin's diagnostics and prognostics associated to the quality of the superficial water, the physical 
vulnerability of the units of landscape were evaluated and integrated to the aspects of socioeconomic dynamics, including the concession of rights to its use. The results are discussed as follows.

\subsection{Evaluation of the water quality}

The largest concentration of metals found in the water was of manganese (0.06$13.42 \mathrm{mg} / \mathrm{l})$, iron $(>0.3 \mathrm{mg} / \mathrm{l})$ and chromium in the points $\mathrm{R} 20(0.05 \mathrm{mg} / \mathrm{l})$ and B3 $(0.08 \mathrm{mg} / \mathrm{l})$.

The hydro chemical parameters at each study point, fig. 1, show that, in general, the tributaries have water with less quality. Improper values of thermotolerant coliforms appear in the stations: R15 $(5320 \mathrm{col} / 100 \mathrm{~mL})$, close to the sewers of the city of Queimadas; R18 (13600 col/100ml), downstream of the city of Jacobina; R22 (3200 col/100mL), a river tributary that receives effluents from Campo Formoso; and B7 $(6300 \mathrm{col} / 100 \mathrm{~mL})$, at the Cariacá dam. The total nitrogen proportions are higher close to populated areas ( $>25,000$ inhabitants), as in the cities of Tucano, Jacobina and Senhor do Bonfim.

The results suggest that the water quality reflects the natural and anthropogenic conditions. The main alterations can be related to the following processes:

- Siltation: the average depth varies in the stations of the river between periods $1(0.8 \mathrm{~m})$ and $2(0.4 \mathrm{~m})$ of the collection sample;

- Eutrophication: the water has an elevated concentration of total phosphor $(0.07-23.95 \mathrm{mg} / \mathrm{l})$, the highest values $(>1500 \mathrm{mg} / \mathrm{l})$ are in the points closest to the cities of greater population of sector I (Senhor do Bonfim and Jacobina);

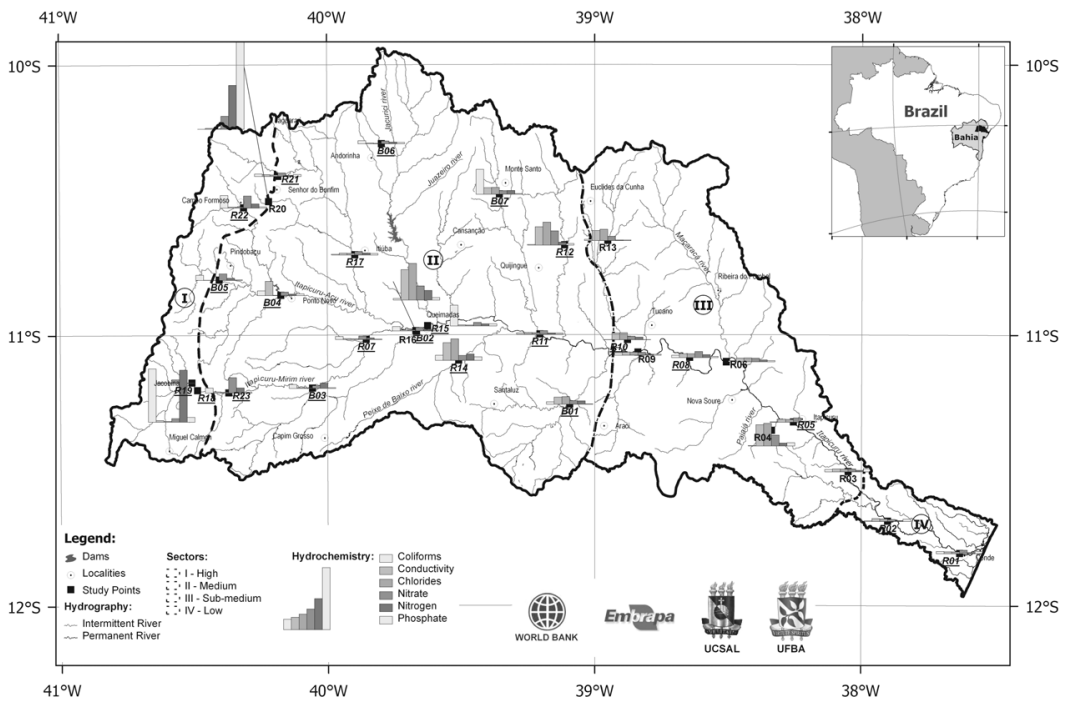

Figure 1: Maximum concentration of parameters in the sample points. 
- Salinization: the points in the middle Itapicuru, where the precipitation is low, show greater values of conductivity $(>600 \mu \mathrm{S} / \mathrm{cm})$ and of chlorides $(>300$ $\mathrm{mg} / \mathrm{l}$;

- Chemical contamination: in the high Itapicuru, where there are more chrome mining activities, the concentration of metals in the sediments is higher.

\subsection{Socio-environmental subsidies for the evaluation of the environmental quality}

The integrated analysis of the physical environmental components of the territory (geology, terrain morphology, drainage density, soils, etc) resulted in the delimiting of homogeneous units of landscape, for which levels of physical vulnerability to the anthropogenic impacts were identified, based on the analysis of the intrinsic sensitivity and resilience of the systems.

The greater vulnerability zones (19\% of the basin's area), fig. 2, are distributed preferably on the northern portion of the basin and on the areas of the coastal plain or estuary region. They are areas with an average precipitation of $1,100 \mathrm{~mm}$ and of high risk of erosion. In sector I are the springs of the main courses of water to the north and in sector IV the sensitive ecosystems.

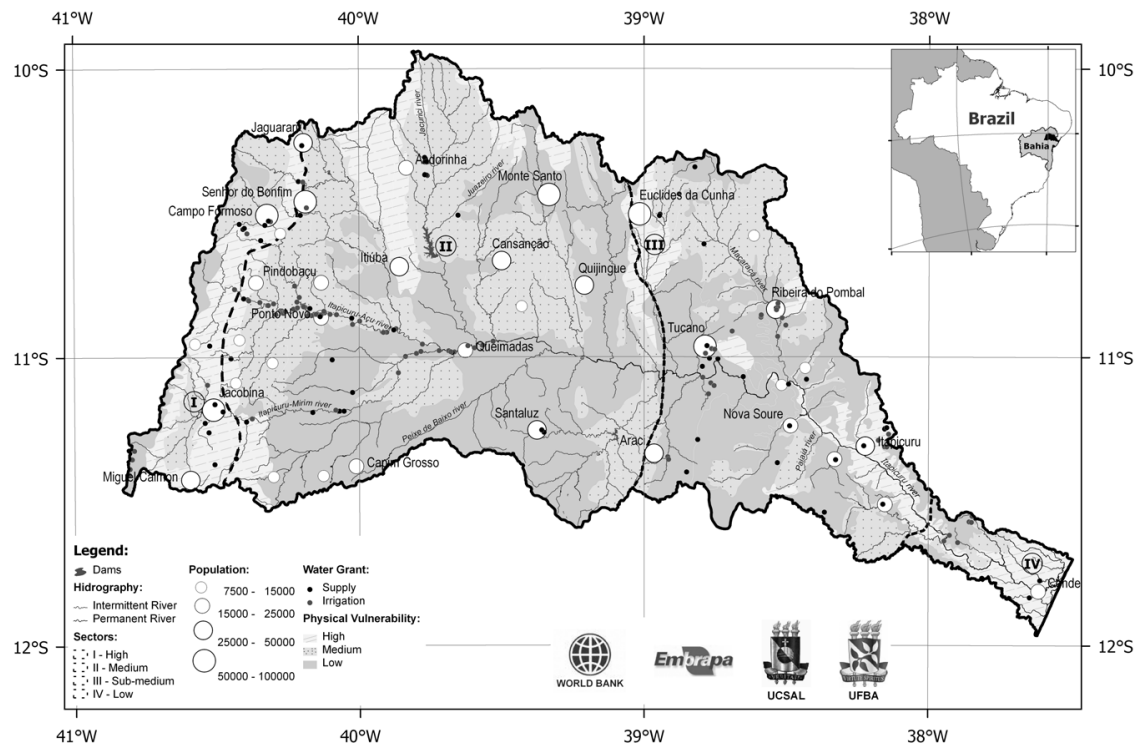

Figure 2: $\quad$ Map of the physical vulnerability associated to the population and water rights grant distribution in the Itapicuru basin.

The zones of medium and low vulnerability occupy, respectively, 35 and $46 \%$ of the basin's area. The areas of greater demographic density are the same as 
those of greater register in water rights grant or predominant use of the water resources (SRH [5]). Around 75\% of the water rights grants are for irrigation and concentrated in the upper and in the middle lower sectors of the Itapicuru, respectively, sectors I and III.

Aiming at conjugating elements to mark the results of the environmental components was tried to understand the level of anthropogenic pressure associated to the economic activities of the basin. From this viewpoint, six homogeneous socio-economic units were delimited and mapped, fig. 3, identified from the analysis of socio-economic indicators, such as: urban population, GDP (Gross Domestic Product), farming activities, areas of mining and industry. The results indicate the low economic dynamism of the basin and confirm the scenery of the quality of superficial waters depicted in this study.

\subsection{Environmental diagnosis and prognosis associated to the quality of the surface water}

Comprehending the environmental quality of a certain territory is always a great challenge, for there are many involved variables and very often the methods used are not sufficient to produce a reading compatible to the scale and object analyzed. As a methodological procedure for the validation of the environmental quality of the Itapicuru basin, were used the indicators related to the environment, productive activities and water quality.

For water quality the indicators TSI and WQI - empirical indices aggregate values of various parameters in a sole numeric indicator. The TSI groups the results of total phosphor and chlorophyll $a$, and the WQI the following parameters: temperature, $\mathrm{pH}$, dissolved oxygen, biochemical demand for oxygen - DBO, coliforms, nitrogen and total phosphor, total solids and turbidness. The metal concentration in the sediment for each point was evaluated for the three levels of standards of the National Oceanographic and Atmospheric Administration - NOAA (Buchman [6]):

TEL - Threshold Effects Levels - Concentration below which adverse effects seldom occur;

PEL - Probable Effects Levels - concentration above which is expected that the adverse effects occur; and

UET Upper Effects Threshold - concentration above which the adverse biological impacts would be expected for a certain bioindicator.

The results, fig. 3 , show that in a good part of the points the TSI indicates the states of mesotrophy and eutrophy or, respectively, with intermediate or high productivity, associated to the areas agriculture and urban sewers. The hipertrophy state is identified in some points of sector I. According to WQI the water quality is good in most part of the basin, especially, in the middle and lower sectors. In sector I the values are of acceptable quality, with only point of improper quality, close to Senhor do Bonfim. The same happens for the TSI. 


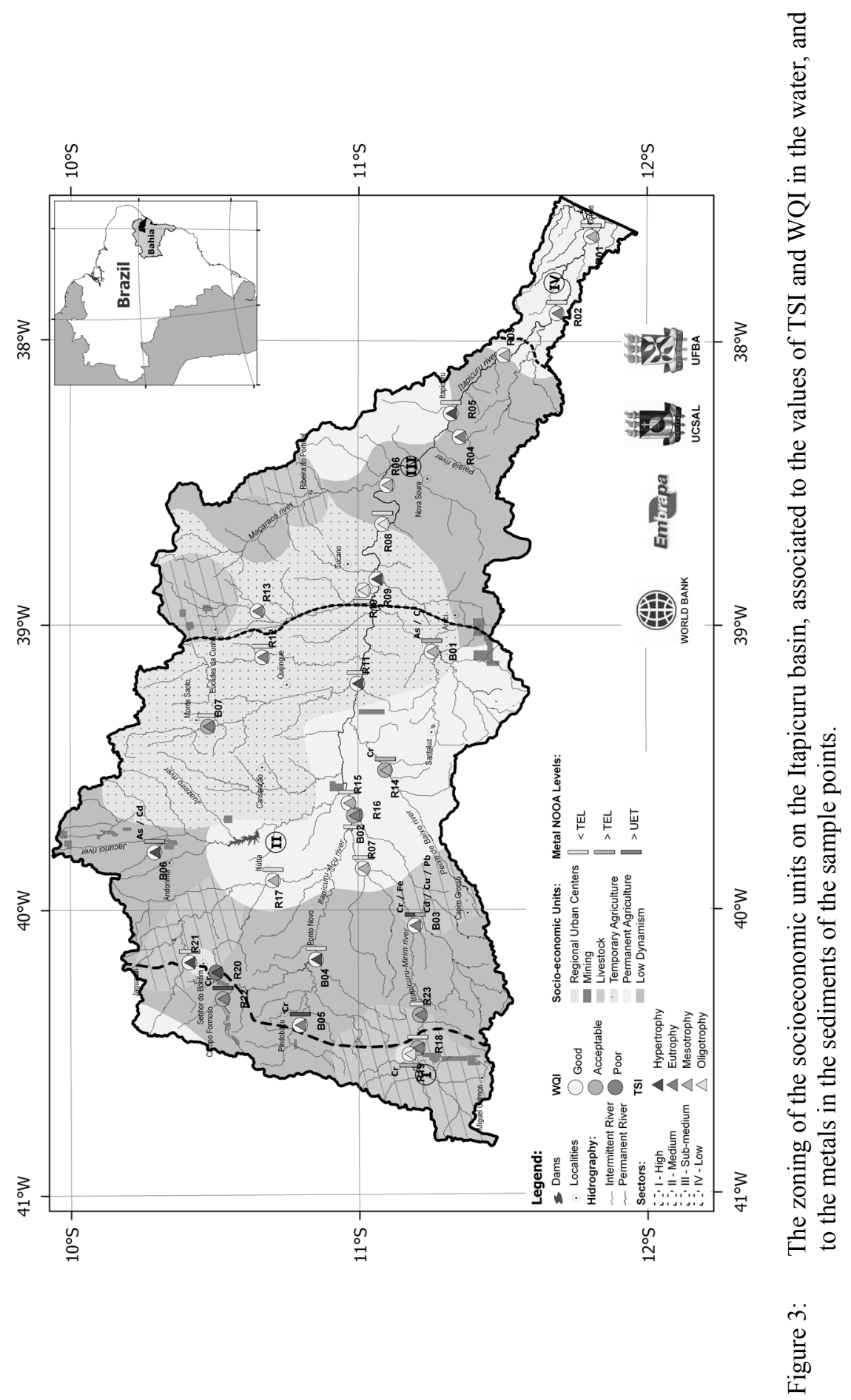

WIT Transactions on Ecology and the Environment, Vol 103, (C) 2007 WIT Press www.witpress.com, ISSN 1743-3541 (on-line) 
The unsuitability of the water is evident in areas of greater population, due to the sewers (residential, commercial, butchery, etc.). Mineral activity is also reflected in punctual results. In most part, the sediments bring metals with values below the TEL level, suggesting the good environmental quality of the basin. Chromium is over the UET level (95 ppm) is found in the dams B3 and B5 and on the point R22, areas with chrome mining activities.

The results lead to the diagnosis that the Itapicuru basin does have a satisfactory environmental quality, especially, related to low economic dynamism. The activities associated to agriculture and livestock have little effect on the GDP of the region and relative influence on the environmental impact on the water. The mineral activity gave dynamism to the economy and concentrated populations in the urban centers of average sizes in the past; today it doesn't promote the region's economic growth. The passive and active environmental impacts associated to the areas with mining activities are also reflected in the quality of the sediments.

\section{Conclusions and recommendations}

The results indicate that the quality of the basin is satisfactory. The productive activities have low polluting potential, and do not generate wealth, a factor that explains the unexpressive GDP per capita of the basin's population. The homogeneous socio-environmental units indicate the large areas where productive activities compatible with the environment's fragility can be implanted. Many areas are in zones of low economic dynamism and demographic density, indicating that there are no governmental actions to promote their sustainable development. The largest population concentrations are located in regional urban centers, given dynamism by the mineral industry that is in decadence. The economic stagnation, in most of the cities of the basin, contributes to soothe the impacts over the water resources.

The evaluation of the quality of the superficial water of the rivers, evaluated in this study shows satisfactory results, in terms of the quality indices defined by many legislation and international organisms. Then, despite the conditions imposed by the semiarid evidenced in the middle section, in general, the quality of the natural resources in the basin is good. However the economy is stagnated and the poverty rates are high. It's expected that the results and achievements of this study or the entire project will be useful to support the development of a management program on the sustainability of water resources, mainly, in order to increasing the economy in the Itapicuru basin.

\section{Acknowledgements}

The authors would like to thank: the PRODETAB/EMBRAPA program for the financial support; the experts at Engequímica and the biologist Wilson de Matos of LEMA/UCSal for the participation in the stages of collection and chemical analysis; GIS Engenharia, especially, Yoshio Urasaki for the structuring of the images; and Carlete Marques for the final translation of this text. 


\section{References}

[1] BAHIA. Secretaria de Meio Ambiente e Recursos Hídricos (SEMARH). Superintendência de Recursos Hídricos. Bacias Hidrográficas da Bahia. Salvador, SRH, 2006. $2^{\mathrm{a}}$ ed. 66 p.

[2] Projeto de Pesquisa para o Apoio ao Desenvolvimento de Tecnologia Agropecuária para o Brasil (PRODETAB). Contribution to an integrated plan for the use and conservation of water resources in the Itapicuru river basin, State of Bahia, Brazil. Projeto 055-01/01 EMPRAPA /FAPEX/UCSAL/UFBA. 2007.

[3] American Public Health Association (APHA-AWWA-WPCF). Standards methods for the examination of water and wastewater. 19th ed. Washington. DC: $1995.1268 \mathrm{p}$.

[4] Carlson, R.E., A trophic state index for lakes. Limnology \& Oceanography, (22), pp. 361-369. 1977.

[5] BAHIA. Secretaria de Recursos Hídricos, Saneamento e Habitação. Superintendência de Recursos Hídricos. Plano Diretor da Bacia do Itapicuru. Salvador, SRH, 1995. 243. http://hidricos.mg.gov.br.

[6] Buchman, M.F. NOAA Screening Quick Reference Tables. NOAA HAZMAT Report 99-1, Seattle WA, Coastal Protection and Restoration Division, National Oceanic and Atmospheric Administration, 1999. 12p. 